\title{
Normative Data for Frequency Specificity of Acoustic Reflex Thresholds
}

\author{
Sunghwa You ${ }^{1,2}$, Saea Kim¹,2, Woojae Han ${ }^{1,2,3}$ \\ ${ }^{1}$ Laboratory of Hearing and Technology, ${ }^{2}$ Division of Speech Pathology and Audiology, ${ }^{3}$ Research Institute of Audiology and Speech Pathology, \\ College of Natural Sciences, Hallym University, Chuncheon, Korea
}

\author{
음향반사역치의 주파수 특이성을 고려한 정상역치의 규준 \\ 유성화 ${ }^{1,2} \cdot$ 김세아 ${ }^{1,2} \cdot$ 한우재 ${ }^{1,2,3}$ \\ 한림대학교 자연과학대학 HearT 실험실', 언어청각학부 ${ }^{2}$ 청각언어연구소 ${ }^{3}$
}

\begin{abstract}
Purpose: Although acoustic reflex thresholds (ART) have widely used to screen and diagnose auditory lesions, they are confined only for measurements in low probe tone. The present study provides normative adults data based on various frequencies of both probe tone and stimuli, and thus extends to discuss any possible clinical application as frequency specificity. Methods: A total of 104 young listeners with normal hearing (53 female and 51 male) participated. After completing hearing screening tests, they performed the ART measurement in twelve conditions consisted of 3 probe tones (e.g., 226, 678, 1,000 Hz) and 4 stimulus frequencies (e.g., 500, 1,000, $2,000,4,000 \mathrm{~Hz}$ ). Individual's thresholds were obtained at each condition and were statistically compared. Results: All data were recorded within the normal range proposed in the classic ART measurement. Interestingly, thresholds conducted at the probe tone of 678 $\mathrm{Hz}$ were slightly higher than those of the other probe tones regardless of a kind of the stimulus frequencies. Also, all probe tones had the highest ART at 4,000 Hz. Conclusion: We obtained the differentiated ART normalize data depending on frequency specificity. In the following study, patients with various pathologies should be applied using same probe tones and their data could be compared in terms of sensitivity and specificity.
\end{abstract}

Key Words: Middle ear muscle, Acoustic reflex thresholds, $678 \mathrm{~Hz}, 1,000 \mathrm{~Hz}$.

Received: September 3, 2019 / Revised: September 29, 2019 / Accepted: October 3, 2019

Correspondence: Woojae Han, Laboratory of Hearing and Technology, Division of Speech Pathology and Audiology, \#8603 Natural Science Building, Hallym University, 1 Hallymdaehak-gil, Chuncheon 24252, Korea

Tel: +82-33-248-2216 / Fax: +82-33-256-3420 / E-mail: woojaehan@hallym.ac.kr

\section{INTRODUCTION}

임상에서 쉽게 접할 수 있는 중이 검사(middle-ear impedance tests)는 제시된 자극음이 고막에서 반사 혹은 흡수된 후 되돌아오는 에너지를 측정하여 중이 진동 체계를 수학적으로 계산할 수 있다. 즉, 고막, 이소골, 이관, 중이강 등 중이 구조물 의 상태 변화를 통하여 질병의 유무를 객관적으로 분석할 수 있는 검사법으로써, 비침습적이며 검사 시간이 짧고 절차가 간 단하다는 이점으로 중이 질환을 포함하여 난청의 선별 및 진단 목적으로 폭넓게 사용되고 있다(Margolis et al., 1999; Wiley

(c) This is an Open Access article distributed under the terms of the Creative Commons Attribution Non-Commercial License (https://creativecommons.org/licenses/by-nc/4.0) which permits unrestricted non-commercial use, distribution, and reproduction in any medium, provided the original work is properly cited. et al., 1987).

중이 구조물 중 이내근은 65 90 dB SL의 큰 소리의 자극에 반사적으로 수축하여 결과적으로 달팽이관에 존재하는 유모 세포를 고강도의 소음 노출로부터 보호하는 역할을 한다 (Counter \& Borg, 1993). 이내근은 추골(malleus)에 부착되어 삼차신경(제5번 뇌신경)의 지배를 받는 고막장근(tensor tympani muscle)과 등골(stapes)에 부착되어 안면신경(제7번 뇌신 경)의 지배를 받는 등골근(stapedius muscle)으로 구성되며 (Mukerji et al., 2010), 특히 등골근이 반사에 주도적 역할을 하 여 등골근 반사 혹은 음향반사(acoustic reflex)라 칭한다. 등골 근이 반사적으로 수축하면 중이의 이미턴스(immittance)에 변 화가 생겨 외이도의 부피를 약 $2 \mathrm{cc}$ 정도 변화시키는데, 이 중 약 $1 \%$ 인 $0.02 \mathrm{cc}$ 의 부피 변화를 확인할 수 있는 최소 강도를 음 
향반사역치(acoustic reflex thresholds)라 정의한다(Parra et al., 2005). 현재 임상에서 가장 일반적으로 사용되는 음향반사 역치는 자극음의 동측(ipsilateral) 혹은 대측(contralateral)의 경로를 $226 \mathrm{~Hz}$ 의 프로브 톤(probe tone)에서 $0.5,1,2,4 \mathrm{kHz}$ 의 자극음(stimulus)을 사용하여 측정한다. 정상 청력인의 음 향반사역치는 약 70 100 dB HL 강도의 자극음에서 나타나며, 이 범위에서 벗어난 정도 및 동측과 대측의 결과를 비교하여 병변 부위의 정보 및 청력 손실 정도를 유추할 수 있다.

Jerger(1970)는 $226 \mathrm{~Hz}$ 의 프로브 톤이 성인 및 유소아의 중 이 기능을 평가하는 데 효과적이라 소개했고, 이후 미국표준협 회(American National Standards Institute, ANSI/ASA S3.39, 1987)는 이미턴스 검사 장비에 $226 \mathrm{~Hz}$ 의 프로브 톤을 사용하 여 음향반사역치를 측정하도록 제정하였다. 그러나 저주파수인 $226 \mathrm{~Hz}$ 의 프로브 톤은 비교적 낮은 공명 주파수를 유발하고 질량에 영향을 받는(mass-dominated) 유소아 중이의 병리적
특성을 정확하게 반영하지 못한다는 한계점이 있다. 그로 인해 Holte et al.(1991)은 유소아에게 $226 \mathrm{~Hz}$ 프로브 톤을 사용하여 중이검사를 실시할 때 낮은 신뢰도의 검사결과를 나타낼 수 있 다고 보고하였다. 따라서 경직성에 주로 영향을 받는(stiffnessdominated) 성인의 중이검사와는 차별화된 검사 방법이 제안 되었고, 유소아 대상 신뢰성 있는 중이검사를 위해서 Himelfarb et al.(1979)과 Marchant et al.(1986)은 $660 \mathrm{~Hz}$ 또는 678 $\mathrm{Hz}$ 의 프로브 톤을, Baldwin(2006)과 Keefe \& Levi (1996)는 $1,000 \mathrm{~Hz}$ 의 프로브 톤 사용을 주장하였다.

한편, 음향반사역치는 고막운동도 검사법과 달리 프로브 톤 에 대한 근거 있는 제안이나 사용 기준의 차별성에서 현재까지 연구가 충분히 이뤄지지 않았다. Table 1 에서 정리한 5 개의 대 표적인 선행연구들 간에도 프로브 톤과 자극음 주파수에 따라 다소 상이한 결과들을 보이고 있다. 예를 들어, Beattie \& Leamy(1975)와 Wilson \& McBride(1978)의 연구에서는 678

Table 1. Summary of literature investigated for wideband probe tone or stimulus frequency

\begin{tabular}{|c|c|c|}
\hline Researcher (year) & Methods & Main findings \\
\hline $\begin{array}{l}\text { Beattie \& Leamy } \\
\text { (1975) }\end{array}$ & $\begin{array}{l}\text { Subject: } 20 \text { adults } \\
\text { Probe tone: } 226 \text { and } 660 \mathrm{~Hz} \\
\text { Stimulus: pure tone and white noise } \\
\text { at } 250,500,1,000,2,000 \text {, and } 4,000 \\
\mathrm{~Hz}\end{array}$ & $\begin{array}{l}\text { The ART by using } 660 \mathrm{~Hz} \text { probe tone were } 2 \text { to } 6 \mathrm{~dB} \text { lower than those of } \\
226 \mathrm{~Hz} \text { probe tone } \\
\text { When applying white noise stimulus, the ART were } 10 \text { to } 20 \mathrm{~dB} \text { lower } \\
\text { than thresholds obtained with pure tones }\end{array}$ \\
\hline $\begin{array}{l}\text { Wilson \& } \\
\text { McBride (1978) }\end{array}$ & $\begin{array}{l}\text { Subject: } 8 \text { adults } \\
\text { Probe tone: } 226 \text { and } 660 \mathrm{~Hz} \\
\text { Stimulus: pure tone and broadband } \\
\text { noise at } 250,500,1,000,2,000 \text {, and } \\
4,000 \mathrm{~Hz}\end{array}$ & $\begin{array}{l}\text { The ART were showed that the } 220 \mathrm{~Hz} \text { probe tone yielding that } 3.5 \mathrm{~dB} \\
\text { higher than those obtained with the } 660 \mathrm{~Hz} \text { probe } \\
\text { Broadband noise and } 1,000 \mathrm{~Hz} \text { stimuli showed the largest reflex } \\
\text { magnitudes, while the smallest were showed by using } 250 \text { and } 4,000 \\
\mathrm{~Hz} \text { stimuli }\end{array}$ \\
\hline $\mathrm{Lu}(1991)$ & $\begin{array}{l}\text { Subject: } 24 \text { adults } \\
\text { Probe tone: } 226,678 \text {, and } 1,000 \mathrm{~Hz} \\
\text { Stimulus: pure tone at } 1,000 \mathrm{~Hz}\end{array}$ & $\begin{array}{l}\text { Admittance and susceptance values at } 226 \mathrm{~Hz} \text { and } 678 \mathrm{~Hz} \text { were large, but } \\
\text { there were no significant differences as compared with those of 1,000 Hz } \\
\text { The average ART for } 25 \text { adults were } 83 \mathrm{~dB} \mathrm{HL} \text { at } 226 \mathrm{~Hz} \text { probe tone, } 91 \\
\mathrm{~dB} \text { at } 678 \mathrm{~Hz} \text {, and } 88 \mathrm{~dB} \text { at } 1,000 \mathrm{~Hz} \text {, based on } 1,000 \mathrm{~Hz} \text { pure tone. } \\
\text { There were significant differences among three probe tones }\end{array}$ \\
\hline Rawool (1998) & $\begin{array}{l}\text { Subject: } 25 \text { adults } \\
\text { Probe tone: } 226,678 \text {, and } 1,000 \mathrm{~Hz} \\
\text { Stimulus: click }\end{array}$ & $\begin{array}{l}\text { The results showed that ART at the } 678 \mathrm{~Hz} \text { probe tone was significantly } \\
\text { higher than the } 226 \text { and } 1,000 \mathrm{~Hz} \text { probe tones } \\
\text { It suggests that either } 226 \mathrm{~Hz} \text { or the } 1,000 \mathrm{~Hz} \text { probe tone can be used for } \\
\text { the measurement of click-evoked ART in adults }\end{array}$ \\
\hline $\begin{array}{l}\text { Peterson \& Lidén } \\
\text { (1972) }\end{array}$ & $\begin{array}{l}\text { Subject: } 67 \text { normal hearing adults and } \\
32 \text { sensorineural hearing loss } \\
\text { Probe tone: } 220,625 \text {, and } 800 \mathrm{~Hz} \\
\text { Stimulus: pure tone and narrowband } \\
\text { noise at } 250,500,1,000,2,000 \text {, and } \\
4,000 \mathrm{~Hz} \text {, and } 600 \mathrm{~Hz} \text { bandwidth }\end{array}$ & $\begin{array}{l}\text { For three probe tones of } 220,625 \text {, and } 800 \mathrm{~Hz}, \mathrm{ART} \text { at } 500 \text { and } 4,000 \mathrm{~Hz} \\
\text { show were not significantly different } \\
\text { Both ipsilateral and contralateral reflexes were more frequently present } \\
\text { for the } 660 \mathrm{~Hz} \text { probe tone, compared to } 220 \mathrm{~Hz} \text { probe tone. However, } \\
\text { the ART did not vary significantly between the probe tones } \\
\text { The ART for the broadband noise were significantly lower than the pure } \\
\text { tone. Also the ipsilateral thresholds were lower than their } \\
\text { contralateral thresholds }\end{array}$ \\
\hline
\end{tabular}

ART: acoustic reflex thesholds 
$\mathrm{Hz}$ 의 프로브 톤에서 측정된 음향반사역치는 $226 \mathrm{~Hz}$ 의 프로 브 톤에서 측정된 음향반사역치보다 약 2 6 dB 정도 낮다고 보고하였지만, Lu(1991)와 Rawool(1998)의 연구에서는 이와 정반대로 $678 \mathrm{~Hz}$ 의 프로브 톤에서 측정한 음향반사역치가 $226 \mathrm{~Hz}$ 와 $1,000 \mathrm{~Hz}$ 의 프로브 톤에서 측정한 역치와 비교 시 유의미하게 높다고 보고하였다. 한편 $220,625,800 \mathrm{~Hz}$ 의 세 가 지 프로브 톤에서 저주파수인 $500 \mathrm{~Hz}$ 와 고주파수인 $4,000 \mathrm{~Hz}$ 의 자극음 주파수에 의해 음향반사역치를 측정했던 Peterson \& Lidén(1972)의 연구에서는 프로브 톤 및 자극음 주파수 변 화에 따라 통계적으로 유의미한 차이가 나타나지 않았지만, 음 향반사역치의 측정에 가장 민감한 프로브 톤은 $220 \mathrm{~Hz}$ 라고 결 론지었다. 마지막으로 Sprague et al.(1985)의 연구에서는 프로 브 톤의 차이 이외에도 광대역 잡음의 자극음은 순음을 자극 음으로 사용하여 측정한 역치보다 훨씬 낮게 음향반사역치가 측정되었다. 정리해 보면 음향반사역치는 프로브 톤 및 자극음 주파수의 특성에 따라 결과에 영향을 줄 수 있기에 임상적으로 객관적이고 신뢰성 있는 분석 및 해석이 무엇보다 중요하다. 이 를 위해 프로브 톤 및 자극음에 따른 음향반사역치의 정상 데 이터를 정립할 필요가 있다. 그러나 기존 선행된 연구들은 비교 적 적은 대상자 수로 인해 표준화하기에 어려우며, 사용된 프로 브 톤 및 자극음 또한 상이하다. 더욱이 현재까지 보고된 결과 들 또한 문헌 간 일치성이 부족하였다. 따라서 본 연구에서는 $226,678,1,000 \mathrm{~Hz}$ 의 프로브 톤과 $500,1,000,2,000,4,000 \mathrm{~Hz}$ 의 자극음에 따른 12 가지 조건에서 음향반사역치의 차이를 분 석하고, 음향 반사에 영향을 미치는 주파수별 특성을 파악하 여 향후 임상 현장에서 적용될 수 있는 표준화된 음향반사역치 를 제시함으로써 보다 정확한 진단 및 결과 해석에 기초가 되 고자 한다.

\section{MATERIALS AND METHODS}

\section{연구 대상}

본 연구는 정상 청력을 가진 20대 성인을 대상으로 프로브 톤 및 자극음 주파수 변화에 따른 음향반사역치를 측정하였다.

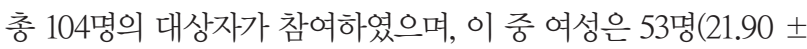
2.00 세), 남성은 51 명(22.08 \pm 2.45 세)이다. 모집된 연구 대상 자들의 정상 청력 여부를 선별하기 위하여 기도 전도 및 골도 전도의 순음청력역치검사와 고막운동도검사(tympanometry)를 실시하였다. 모든 연구 대상자들은 $125 \sim 8,000 \mathrm{~Hz}$ 의 순음청력검 사 주파수 대역에서 $15 \mathrm{~dB} \mathrm{HL}$ 이하의 기도 및 골도 역치와 500 $4,000 \mathrm{~Hz}$ 의 주파수 대역에서 $5 \mathrm{~dB}$ 이내의 기도-골도 역치 차 이를 나타내었고, A-type의 정상적인 고막운동도검사 결과를 보였다. 연구 대상자들은 실험 참여 전 연구의 목적과 절차에
대하여 설명을 듣고 연구에 대해 충분히 이해한 뒤 참여 동의서 에 서명하였다.

\section{연구 장비 및 절차}

음향반사역치 검사는 GSI Tympstar Middle Ear Analyzer (Ver. 2, Grason-Stadler, Eden Prairie, MN, USA)를 사용하 여 연결된 프로브 팁으로 외이도를 완전히 밀폐한 뒤 측정하였 다. 측정 시 $226,678,1,000 \mathrm{~Hz}$ 의 세 가지 주파수의 프로브 톤 과 $500,1,000,2,000,4,000 \mathrm{~Hz}$ 의 네 가지 자극음 주파수의 결 합인 총 12 개의 조건을 의사 무작위 추출(pseudo randomly) 방 식으로 연구 대상자에게 제시하여 음향반사역치를 측정하였다.

초기 소리 제시 강도는 $80 \mathrm{~dB} \mathrm{HL}$ 에서 시작하여 $5 \mathrm{~dB}$ 간격 으로 상승 혹은 하강하면서 3 번 자극 시 2번 이상 반응 수준을 역치로 측정하였고, 프로브 톤 차이에 따른 등골근의 자극 및 수축은 Parra et al.(2005) 및 Rawool(1998)의 연구에 근거하여 기준을 따랐다. 즉, $226 \mathrm{~Hz}$ 는 진폭이 $0.02 \mathrm{~mL}$ 이상으로 측정 되는 가장 작은 소리의 크기를 역치로 판정하였으며, $678 \mathrm{~Hz}$ 는 $0.06 \mathrm{mmho}$ 를, $1,000 \mathrm{~Hz}$ 는 $0.09 \mathrm{mmho}$ 를 기준으로 각 연구 대 상자의 역치를 판정하고 기록하였다.

\section{데이터 및 통계 분석}

정상역치의 규범화를 위해 연구 대상자 104 명의 양이의 측 정 결과인 총 208개의 데이터 중 90-percentile에 해당하는 데 이터만 선정하였다. 즉, 수집된 208개 데이터의 정규 분포를 확 인하고, 평균 중심으로부터 가장 먼 양쪽 꼬리(tail)의 $5 \%$ 씩의 자료를 제거한 후 분석되었다(Swanepoel et al., 2007). 정리된 자료는 통계프로그램인 SPSS (Ver. 25, IBM Corp., Armonk, $\mathrm{NY}, \mathrm{USA}$ )를 이용하여 거시적으로 반복측정 이원배치분산분 석[two-way analysis of variance (ANOVA) with repeated measures]을 통해 프로브 톤과 자극음의 주파수에 따른 음향 반사역치에 대한 통계적 유의성을 확인하였고, 미시적으로는 각 프로브 톤에서 자극음 주파수에 따른 음향반사역치를 반복 측정 일원배치분산분석(one-way ANOVA with repeated measures)으로 확인하였다. 필요 시 Bonferroni correction에 의해 사후 분석을 실시하였다. 본 연구에 사용된 통계적 유의 미 수준은 $p<0.05$ 였다.

\section{RESULTS}

Figure 1은 프로브 톤과 자극음 주파수의 변화에 따른 12개 의 검사 조건에서 104 명의 음향반사역치 분포를 상자그림(box plot)으로 표현하였다. 먼저 $226 \mathrm{~Hz}$ 프로브 톤에서 500, 1,000, $2,000,4,000 \mathrm{~Hz}$ 자극음 주파수의 음향반사역치 평균은 각각 


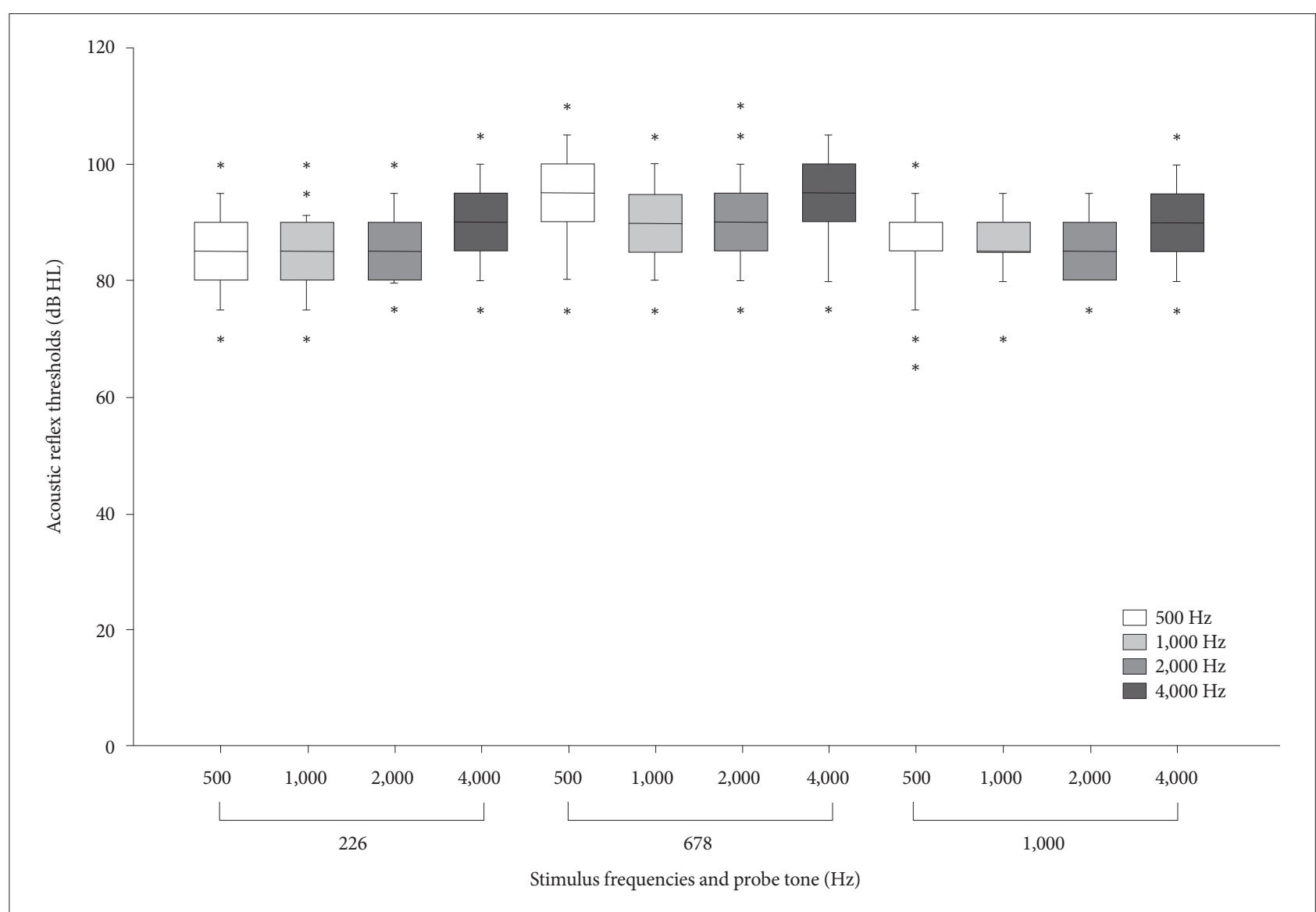

Figure 1. Average comparison of acoustic reflex thresholds in four stimulus frequencies $(500,1,000,2,000$, and $4,000 \mathrm{~Hz})$ based on the probe tone $(226,678$, and $1,000 \mathrm{~Hz})$.

84.94, 84.03, 86.49, $89.97 \mathrm{~dB}$ HL로 나타났다. $678 \mathrm{~Hz}$ 의 프로 브 톤을 기준으로는 4 가지의 자극음 주파수에서 각각 93.80 , 90.78, 91.07, $94.38 \mathrm{~dB}$ HL으로, $1,000 \mathrm{~Hz}$ 프로브 톤 기준은 $86.79,86.92,86.43,90.29 \mathrm{~dB}$ HL로 나타났다. 기술통계분석 결과, 자극음의 주파수에 상관없이 프로브 톤이 $678 \mathrm{~Hz}$ 일 때 음향반사역치가 전반적으로 높게 나타났다.

프로브 톤 및 자극음의 주파수에 따라 음향반사역치의 유의 미성을 확인하기 위해 반복측정 이원분산분석을 시행하였으 며, 통계 분석 결과는 Table 2에 요약하였다. 주 효과로 구분된 프로브 톤 $[\mathrm{F}(2,232.92)=81.98, p=0.000]$ 과 자극음 주파수 $[\mathrm{F}(2.28,349.17)=51.05, p=0.000]$ 에서 모두 통계적으로 유의 미한 차이를 나타내었고, 이는 프로브 톤 및 자극음의 주파수 의 변화에 따라 음향반사역치가 유의미하게 영향을 받았음을 의미하였다. 프로브 톤에 따른 역치 변화의 사후 분석 결과, 세 가지의 프로브 톤 간 모두 유의미한 역치 차이를 나타냈다 $(p<$ 0.01). 즉, $678 \mathrm{~Hz}$ 의 프로브 톤에서 측정된 음향반사역치는 $92.51 \mathrm{~dB}$ 로 $226 \mathrm{~Hz}$ 에서 측정된 $86.36 \mathrm{~dB}$ 의 음향반사역치보다 통계적으로 $6.15 \mathrm{~dB}$ 의 차이를 보였고, 이는 $1,000 \mathrm{~Hz}$ 에서 측정 된 $87.61 \mathrm{~dB}$ 의 역치보다 통계적으로 $4.90 \mathrm{~dB}$ 더 높게 나타났다.
각 프로브 톤에서 네 가지의 자극음 주파수에 따른 음향반 사역치는 반복측정 일원분산분석 시 모두 유의미하게 나타났 다(Table 3). 먼저 $226 \mathrm{~Hz}$ 프로브 톤에서는 $4,000 \mathrm{~Hz}$ 자극음 제시에서 $89.97 \mathrm{~dB}$ [standard deviation (SD): 0.54]로 가장 역 치가 높았고, 그 다음은 $2,000 \mathrm{~Hz}$ 에서 $86.49 \mathrm{~dB}$ (SD: 0.49)로 기록되었다. $500 \mathrm{~Hz}$ 와 $1,000 \mathrm{~Hz}$ 는 각각 $84.03 \mathrm{~dB}$ (SD: 0.46)과 $84.93 \mathrm{~dB}$ (SD: 0.49)로 가장 낮은 음향반사역치를 보였다. 또한 $678 \mathrm{~Hz}$ 와 $1,000 \mathrm{~Hz}$ 의 프로브 톤에서도 $4,000 \mathrm{~Hz}$ 의 자극음 주 파수가 제시될 때 각각 $94.38 \mathrm{~dB}(\mathrm{SD}: 0.65)$ 과 $90.29 \mathrm{~dB}(\mathrm{SD}$ : 0.54)로 가장 높은 역치를 나타내었다. 그러나 사후 분석 결과 에서 보인 자극음 주파수의 순서는 다소 상이하였다. 즉, 678 $\mathrm{Hz}$ 의 프로브 톤에서는 4,000, 500, 2,000, 1,000 Hz의 자극음 주파수의 순서로 역치가 낮아졌다. 그러나 $500 \mathrm{~Hz}$ 는 $1,000 \mathrm{~Hz}$ 및 2,000 Hz와 유의미한 차이를 보이지 않았다. $226 \mathrm{~Hz}$ 에서는 $500 \mathrm{~Hz}$ 와 $1,000 \mathrm{~Hz}$ 간 유의미한 역치 차이를 보이지 않았으며, $1,000 \mathrm{~Hz}$ 프로브 톤에서는 $4,000 \mathrm{~Hz}$ 를 제외하고는 세 개의 자 극음 주파수 간 유의미한 역치 차이를 보이지 않았다.

더불어 프로브 톤과 자극음의 상호작용 $[\mathrm{F}(5.28,801.20)=$ 25.22, $p=0.000]$ 에서도 통계적으로 유의한 차이를 보였다. 이 
Table 2. A statistical summary of the results as the probe tone and stimulus frequencies

\begin{tabular}{|c|c|c|c|c|c|}
\hline Analysis & Type III sum of squares & $\mathrm{df}$ & Mean squares & $\mathrm{F}$ & $p$-value \\
\hline \multicolumn{6}{|l|}{ Main effect } \\
\hline Probe tone & $13,928.90$ & 2 & $6,514.45$ & 81.98 & $0.000^{*}$ \\
\hline Error & $24,316.94$ & 232.92 & 104.40 & & \\
\hline Stimulus & $4,947.88$ & 2.28 & $2,168.11$ & 51.05 & $0.000^{*}$ \\
\hline Error & $14,829.21$ & 349.17 & 42.47 & & \\
\hline \multicolumn{6}{|l|}{ Interaction } \\
\hline Probe tone $\times$ stimulus & $1,288.53$ & 5.28 & 246.06 & 25.22 & $0.000^{*}$ \\
\hline Error & $7,815.64$ & 801.20 & 9.76 & & \\
\hline
\end{tabular}

Table 3. A statistical summary of the results for the four stimulus frequencies in the probe tone

\begin{tabular}{ccccc}
\hline Probe tone $(\mathrm{Hz})$ & $\mathrm{F}$ & $\mathrm{df}$ & $p$-value & Post-hoc \\
\hline 226 & 64.78 & 2,38 & $0.000^{*}$ & $4,000>2,000>500$ and 1,000 \\
678 & 35.31 & 2,68 & $0.000^{*}$ & $4,000>2,000>1,000$ \\
& & & & $500>2,000>1,000$ \\
1,000 & 27.50 & 2,31 & $0.000^{*}$ & $4,000>1,000,500$, and 2,000 \\
\hline
\end{tabular}

${ }^{*} p<0.01$

는 $678 \mathrm{~Hz}$ 의 프로브 톤에서 기록된 높은 역치에 비해 $226 \mathrm{~Hz}$ 와 $1,000 \mathrm{~Hz}$ 의 프로브 톤에서 낮게 나타나 역치들 간 상호작 용의 패턴으로 분석된다.

\section{DISCUSSIONS}

본 연구는 정상 청력을 지닌 104명의 성인 남녀를 대상으로 $226,678,1,000 \mathrm{~Hz}$ 의 세 가지 프로브 톤에 따른 네 가지 자극 음 주파수인 $500,1,000,2,000,4,000 \mathrm{~Hz}$ 에서 측정된 음향반 사역치를 분석하고, 결과에 영향을 미치는 주파수별 특성을 파 악하여 향후 성인 환자들에게 차별화된 임상적 적용을 위한 기초 자료를 마련하고자 하였다.

먼저, 세 가지 프로브 톤의 주파수와 네 가지 자극음 주파수 로 구성된 총 12 가지 측정 조건 모두에서 음향반사역치는 70 100 dB HL의 정상 기준으로 잘 나타났다. 이는 $220 \mathrm{~Hz}$ 와 $660 \mathrm{~Hz}$ 의 프로브 톤에서 $1,000 \mathrm{~Hz}$ 의 자극음을 사용하여 측 정한 Sprague et al.(1985)의 연구 결과인 $82.6 \pm 8.8 \mathrm{~dB}$ HL과 $81.7 \pm 12.0 \mathrm{~dB} \mathrm{HL}$ 과도 유사하다. 더불어 $220 \mathrm{~Hz}$ 와 $660 \mathrm{~Hz}$ 에서 본 연구와 동일하게 네 가지의 자극음 주파수를 사용한 Beattie \& Leamy(1975)와 Wilson \& McBride(1978)의 연구결 과인 84.5 94.0 dB HL에서의 음향반사역치가 분석된 것과 높 은 일치성을 보인다.

각 자극음 변화를 중심으로 음향반사역치의 차이를 확인해 보았을 때 자극음 주파수 변화에 따라 유의미한 차이를 나타 내었다. 비록 모든 자극음 주파수에 따라 유의미한 변화를 보 이진 않았지만, $4,000 \mathrm{~Hz}$ 에서 가장 높은 음향반사역치를 나타
내었다. 그러나 $226 \mathrm{~Hz}$ 에서는 $500 \mathrm{~Hz}$ 와 $1,000 \mathrm{~Hz}$ 에 유의미한 차이가 없었고, $678 \mathrm{~Hz}$ 에서는 $4,000 \mathrm{~Hz}$ 및 $500 \mathrm{~Hz}$ 에 유의한 차 이가 나타나지 않았다. 또한 $1,000 \mathrm{~Hz}$ 프로브 톤에서는 1,000 $\mathrm{Hz}, 500 \mathrm{~Hz}, 2,000 \mathrm{~Hz}$ 세 자극음 주파수 간 유의한 차이가 없 었다. 즉, Figure 1을 통해 보다 직관적으로 볼 수 있듯이 4,000 $\mathrm{Hz}$ 에서 높은 역치 값 이외의 주파수별 역치 차이에 대한 어떠 한 특성을 짓기엔 어려움이 있었다. 그럼에도 본 연구에서는 흥 미롭게도 $678 \mathrm{~Hz}$ 의 프로브 톤은 $226 \mathrm{~Hz}$ 와 $1,000 \mathrm{~Hz}$ 의 프로 브 톤과 비교할 시 통계적으로 유의미하게 높은 역치가 나타났 다. 이러한 결과는 Lu(1991), Rawool(1998) 및 Parra et al. (2005)의 선행연구들의 결과와 일치하지만, $660 \mathrm{~Hz}$ 프로브 톤 에 더 낮은 역치를 보였던 Beattie \& Leamy(1975)와 Wilson $\& \mathrm{McBride}(1978)$ 의 연구와는 상이하였다. 즉, 전체적인 평균치 에는 높은 일치성을 보이지만 각 프로브 톤을 기준으로 확인해 보았을 때, 연구별로 다른 결과값을 확인할 수 있다. 이러한 선 행연구들 간 차이점은 음향반사역치의 판별 기준 및 방법에 기 인한 것으로 고려된다. 예를 들어 220 및 $660 \mathrm{~Hz}$ 의 프로브 톤 을 사용했던 Beattie \& Leamy(1975)의 연구에서는 음향반사 역치 판별 기준을 육안 관찰을 통해 $220 \mathrm{~Hz}$ 는 $0.5 \mathrm{mmho}$ 의 변 화량을, $660 \mathrm{~Hz}$ 는 $1 \mathrm{mmho}$ 의 변화량을 기준으로 하였으며, Wilson \& Mcbride(1978)는 오실로스코프(oscilloscope)를 기 준으로 육안으로 변동을 확인할 수 있는 정도의 가장 작은 강 도를 음향반사역치로 정의 및 판별하였다. Peterson \& Lidén (1972) 또한 자극음이 제시되었을 때, 강도 및 위상의 변화를 육안으로 확인할 수 있는 가장 작은 강도를 음향반사역치로 정 의하였다. 앞서 지속적으로 언급되는 육안으로 식별할 수 있는, 
즉 육안 관측은 낮은 신뢰도 및 검사자 간 차이를 유발할 수 있는 등 여러 단점이 존재한다. 따라서 본 연구에서는 중이의 어드미턴스(admittance)의 변화를 전산화 측정(computerized measurements) 및 Parra et al.(2005)과 Rawool(1998)의 연구 에서 제시한 보다 과학적인 수치에 근거하여 각 프로브 톤의 주파수별 어드미턴스 변화 기준으로 측정하였다.

더 나아가 $678 \mathrm{~Hz}$ 프로브 톤에서 상대적으로 높은 역치 값 을 나타낸 또 다른 이유로는 각 프로브 톤이 중이 진동 체계에 미치는 영향으로 분석된다. Rawool(1998)의 연구에 따르면 226 $\mathrm{Hz}$ 의 저주파수 프로브 톤은 중이의 임피던스를 증가시키며, 이는 곧 어드미턴스의 감소를 일으킨다. 이와 반대로 프로브 톤 이 증가할 때 임피던스는 감소하며, 어드미턴스는 증가한다. 이 러한 임피던스, 어드미턴스의 변환이 일어나는 지점은 600 $700 \mathrm{~Hz}$ 대역으로 추정된다(Rawool, 1998). 보다 구체적으로 Bennett \& Weatherby(1979)는 약 $660 \mathrm{~Hz}$ 대역에 임피던스와 어드미턴스의 전환이 일어나는 것으로 보고하였으며, Rawool (1998)은 $678 \mathrm{~Hz}$ 이하 주파수 대역을 제안한다. 그러나 $\mathrm{Ra}^{-}$ wool(1998)의 연구에서 보고하였듯 약 58\%의 대상자는 678 $\mathrm{Hz}$ 보다 높은 주파수에 전환점이 존재하였고, 나머지 $42 \%$ 는 $678 \mathrm{~Hz}$ 보다 낮은 주파수 대역에 존재하여, $678 \mathrm{~Hz}$ 에서 상승된 역치를 보인 본 연구와 일치하는 결과를 보고한다. 또한 $\mathrm{Ra}^{-}$ wool(1998)에 따르면 어드미턴스 변환 지점 이상의 주파수 $(1,000 \mathrm{~Hz})$ 의 경우, $226 \mathrm{~Hz}$ 와 반대로 임피던스의 감소 및 어드 미턴스의 증가를 유발한다. 그로 인해 $678 \mathrm{~Hz}$ 에서 상승되었던 음향반사역치가 $226 \mathrm{~Hz}$ 와 유사한 정도로 감소하는 경향을 나 타낸다. 다시 말해 변환 지점 이상으로 주파수가 증가함에 따 라 질량 리액턴스(mass reactance)는 주파수에 비례하여 증가 하며, 경직성 리액턴스(stiffness reactance)는 비례적으로 감소 하게 된다. 따라서 질량에 영향을 받는(mass-dominated) 고주 파수 범위 즉, 변환 지점 이상 $(1,000 \mathrm{~Hz}$ 프로브 톤)의 주파수에 서는 어드미턴스가 증가하게 되고, 이러한 결과는 $226 \mathrm{~Hz}$ 와 유 사한 음향반사역치를 보도한 본 연구의 결과와도 일치한다. 종 합적으로 본 연구에서 나타난 $678 \mathrm{~Hz}$ 의 상대적으로 높은 역치 는 연구별 역치 산정 기준의 상이함 및 프로브 톤의 차이와 어 드미턴스 변환 지점의 개인차와 같은 피검자의 내재적 요인의 영향이 반영된 것으로 고려된다. 서론에서 언급되었듯이 유소 아를 대상으로 저주파수 프로브 톤의 사용은 낮은 신뢰도로 인해 부적절할 수 있다. 즉, 유소아의 중이 상태를 확인하기 위 해서는 $660 \mathrm{~Hz}$ 혹은 $1,000 \mathrm{~Hz}$ 의 프로브 톤이 제안되었다 (Baldwin, 2006; Himelfarb et al., 1979; Keefe \& Levi, 1996; Marchant et al., 1986). 그러나 이러한 선행연구들의 제안들이 전적으로 유소아에게만 해당하는 것은 아니다. 보다 구체적으 로 성인들을 대상으로 시행한 여러 선행연구들을 분석해 보면
이소골 병변 및 중이 질환을 진단하는 경우 저주파수 프로브 톤은 낮은 신뢰도를 나타낸다. 예를 들어 $275 \mathrm{~Hz}$ 프로브 톤으 로 중이검사를 시행했던 Margolis \& Goycoolea(1993)와 Margolis et al.(1998)의 연구에 따르면 저주파수 프로브 톤은 중이 염(otitis media), 이경화증(otosclerosis), 선천성 이소골 유착 (congenital fixation of ossicles), 골형성 부진증(osteogenesis imperfecta) 등 이소골 병변을 진단하는 데도 적절하지 못하다 고 결론지었고 그 원인으로 공명 주파수를 언급하였다. 즉, 여 러 중이 질환들로 인해 중이의 경직성 및 질량이 변화하며 이 는 공명 주파수에 영향을 미치게 된다. 따라서 단순히 유소아 및 성인의 연령에 따른 프로브 톤 사용의 구분이 아닌, 환자의 질환 및 그에 따른 병리적 특성을 고려하여 검사 및 결과 해석 이 진행되어야 할 것이다. 더불어 최근 국외 임상 현장에서 시 행되고 있는 여러 개의 주파수를 동시에 실시하는 광대역 프로 브 톤(wideband or multifrequency probe tone) 혹은 서로 다 른 주파수의 프로브 톤을 활용한 음향반사의 측정은 단일 프 로브 톤에 비해 중이의 경직성(stiffness), 질량(mass) 그리고 마 찰(frictional) 요소에 대한 더 많은 진단 정보를 제공할 수 있 을 것이다(Mazlan et al. 2007).

결론적으로, 본 연구에서 정상 청력을 가진 20 대의 남녀를 대상으로 음향반사역치 측정 시 $226 \mathrm{~Hz}$ 및 $1,000 \mathrm{~Hz}$ 의 프로 브 톤은 음향반사역치를 유사하게 측정할 수 있던 반면, 678 $\mathrm{Hz}$ 프로브 톤은 음향반사를 유발하기에 더 높은 강도가 필요 하였다. 평균 역치가 가장 낮은 프로브 톤은 $220 \mathrm{~Hz}$, 편차가 가 장 적은 프로브 톤은 $1,000 \mathrm{~Hz}$ 로 가장 안정적이었다. 또한 프 로브 톤에 관계없이 $4,000 \mathrm{~Hz}$ 자극음에 가장 높은 음향반사역 치를 나타내었다. 따라서 본 연구는 성인을 대상으로 음향반사 역치를 측정할 때 $226 \mathrm{~Hz}$ 또는 $1,000 \mathrm{~Hz}$ 프로브 톤을 사용하 는 것이 적합함을 제안하고자 한다. 또한 $226 \mathrm{~Hz}$ 프로브 톤이 유소아에게 신뢰도가 낮을 수 있고, 중이의 생리적 특성상 저주 파수 프로브 톤은 임피던스를 증가시키고 $660 \mathrm{~Hz}$ 또는 1,000 $\mathrm{Hz}$ 의 고주파수 프로브 톤은 어드미턴스가 증가된다는 점을 고 려한다면, 본 연구에서 정립된 각 프로브 톤 및 자극음 주파수 별 음향반사역치는 광대역 프로브 톤의 측정 및 해석의 기초 자료가 될 수 있을 것이고, 추후 다양한 병리적 특성을 지닌 환 자들을 대상으로 이과적 진단을 하는 데 주파수별 차별성을 제공할 것으로 기대한다. 그러나 본 연구에서는 성인만을 대상 으로 측정되었으며 다양한 연령군 및 성별에 대한 데이터는 포 함되지 않은 한계점을 지니고 있다. 따라서 프로브 톤에 따라 성인과 다른 양상을 나타내는 유소아의 특성을 고려한 정상 청 력 유소아의 주파수에 따른 데이터의 정립 또한 매우 중요할 것이다. 후속 연구로서 남녀의 성별을 고려하고, 중이 구조물의 물리적 차이가 발생하는 어린 소아부터 성인 및 노인에 이르는 
다양한 연령대에 따른 음향반사역치에 대한 연구가 필요하며, 이를 바탕으로 다양한 병리적 특성을 지닌 환자들을 대상으로 비교 가능한 결과는 보다 객관적이고 과학적인 진단 및 해석을 용이하게 할 것이라 생각한다.

중심 단어 : 중이근 ·음향반사역치· $678 \mathrm{~Hz} \cdot 1,000 \mathrm{~Hz}$.

\section{Ethical Statement}

This study was approved by the Institutional Review Board of Hallym University (HIRB-2018-014).

\section{Acknowledgments N/A}

\section{Declaration of Conflicting Interests}

There are no conflict of interests.

\section{Funding}

This research was completed while being supported by National Research Foundation of Korea (NRF-2017R1A1A1A05001299).

\section{Author Contributions}

All authors contributed equally to this work. The authors discussed the results altogether and implications and commented on the manuscript at each stage. In detail, S.K. and W.H. designed performed experiments, S.K. collected data, and S.Y. analyzed data and wrote a draft of the paper. Also, W.H. reviewed the final version of the paper as the corresponding author.

\section{ORCID iDs}

Sunghwa You

Woojae Han

https://orcid.org/0000-0003-2458-4509

https://orcid.org/0000-0003-1623-9676

\section{REFERENCES}

American National Standards Institute. (1987). ANSI/ASA S3.39: 1987 (R2012). Specifications for Instruments to Measure Aural Acoustic Impedance and Admittance (Aural Acoustic Immittance). New York, NY: ANSI.

Baldwin, M. (2006). Choice of probe tone and classification of trace patterns in tympanometry undertaken in early infancy. International Journal of Audiology, 45(7), 417-427.

Beattie, R. C. \& Leamy, D. P. (1975). Otoadmittance: Normative values, procedural variables, and reliability. Ear and Hearing, 1(1), 21-27.

Bennett, M. J. \& Weatherby, L. A. (1979). Multiple probe frequency acoustic reflex measurements. Scandinavian Audiology, 8(4), 233-239.

Counter, S. A. \& Borg, E. (1993). Acoustic middle ear muscle reflex protection against magnetic coil impulse noise. Acta Oto-Laryngologica, 113 (4), 483-488.

Himelfarb, M. Z., Popelka, G. R., \& Shanon, E. (1979). Tympanometry in normal neonates. Journal of Speech, Language, and Hearing Research, 22(1), 179-191.

Holte, L., Margolish, R. H., \& Cavanaugh, R. M. (1991). Developmental changes in multifrequency tympanograms. Audiology, 30(1), 1-24.

Jerger, J. (1970). Clinical experience with impedance audiometry. Archives of Otolaryngology, 92(4), 311-324.

Keefe, D. H. \& Levi, E. (1996). Maturation of the middle and external ears: Acoustic power-based responses and reflectance tympanometry. Ear and Hearing, 17(5), 361-373.

Lu, J. (1991). Impedance audiometry with 3-probe frequency. Zhonghua Er Bi Yan Hou Ke Za Zhi, 26(5), 281-283, 317.

Marchant, C. D., McMillan, P. M., Shurin, P. A., Johnson, C. E., Turczyk, V. A., Feinstein, J. C., et al. (1986). Objective diagnosis of otitis media in early infancy by tympanometry and ipsilateral acoustic reflex thresholds. The Journal of Pediatrics, 109(4), 590-595.

Margolis, R. H. \& Goycoolea, H. G. (1993). Multifrequency tympanometry in normal adults. Ear and Hearing, 14(6), 408-413.

Margolis, R. H., Saly, G. L., \& Keefe, D. H. (1999). Wideband reflectance tympanometry in normal adults. The Journal of the Acoustical Society of America, 106(1), 265-280.

Margolis, R. H., Schachern, P. L., \& Fulton, S. (1998). Multifrequency tympanometry and histopathology in chinchillas with experimentally produced middle ear pathologies. Acta Oto-Laryngologica, 118(2), 216225.

Mazlan, R., Kei, J., Hickson, L., Stapleton, C., Grant, S., Lim, S., et al. (2007). High frequency immittance findings: Newborn versus six-week-old infants. International Journal of Audiology, 46(11), 711-717.

Mukerji, S., Windsor, A. M., \& Lee, D. J. (2010). Auditory brainstem circuits that mediate the middle ear muscle reflex. Trends in Amplification, 14(3), 170-191.

Parra, G. F. A., Carvallo, R. M. M., \& Nakagawa, L. (2005). Acoustic Reflexes Elicited Through 678 and $1.000 \mathrm{~Hz}$ Probe-Tone in Adults without Auditory Complaint. International Archives of Otorhinolaryngology. Retrieved from http://www.arquivosdeorl.org.br/additional/acervo_ eng. asp? Id $=300$.

Peterson, J. L. \& Lidén, G. (1972). Some static characteristics of the stapedial muscle reflex. Audiology, 11(1-2), 97-114.

Rawool, V. W. (1998). Effect of probe frequency and gender on click-evoked ipsilateral acoustic reflex thresholds. Acta Oto-Laryngologica, 118(3), 307-312.

Sprague, B. H., Wiley, T. L., \& Goldstein, R. (1985). Tympanometric and acoustic-reflex studies in neonates. Journal of Speech and Hearing Research, 28(2), 265-272.

Swanepoel, de W., Werner, S., Hugo, R., Louw, B., Owen, R., \& Swanepoel, A. (2007). High frequency immittance for neonates: A normative study. Acta Oto-Laryngologica, 127(1), 49-56.

Wiley, T. L., Oviatt, D. L., \& Block, M. G. (1987). Acoustic-immittance measures in normal ears. Journal of Speech and Hearing Research, 30(2), 161170.

Wilson, R. H. \& McBride, L. M. (1978). Threshold and growth of the acoustic reflex. The Journal of the Acoustical Society of America, 63(1), 147-154. 